\title{
Severe inflammatory defect and reduced viability in CD18 and E-selectin double-mutant mice
}

\author{
S.B. Forlow, ${ }^{1}$ E.J. White, ${ }^{1}$ S.C. Barlow, ${ }^{2}$ S.H. Feldman, ${ }^{3}$ H. Lu, ${ }^{4}$ \\ G.J. Bagby, ${ }^{5}$ A.L. Beaudet, ${ }^{4}$ D.C. Bullard, ${ }^{2}$ and K. Ley ${ }^{1}$ \\ ${ }^{1}$ Department of Biomedical Engineering, University of Virginia School of Medicine, Charlottesville, Virginia, USA \\ ${ }^{2}$ Department of Comparative Medicine, University of Alabama at Birmingham, Birmingham, Alabama, USA \\ ${ }^{3}$ Center for Comparative Medicine, University of Virginia Health System, Charlottesville, Virginia, USA \\ ${ }^{4}$ Department of Molecular and Human Genetics, Baylor College of Medicine, Houston, Texas, USA \\ ${ }_{5}^{5}$ Department of Physiology, Louisiana State University Health Sciences Center, New Orleans, Louisiana, USA
}

Address correspondence to: Klaus Ley, University of Virginia, Department of Biomedical Engineering, Health Sciences Center, Box 800759, Charlottesville, Virginia 22908, USA. Phone: (804) 924-1722; Fax: (804) 982-3870; E-mail: kfl3f@virginia.edu.

Received for publication June 12, 2000, and accepted in revised form November 6, 2000.

CD18-deficient mice ( $C D 18^{-/-}$mice) have a severe leukocyte recruitment defect in some organs, and no detectable defect in other models. Mice lacking E-selectin $\left(C D 62 E^{-/-}\right.$mice $)$have either no defect or a mild defect of neutrophil infiltration, depending on the model. $C D 18^{-/-} C D 62 E^{-/-}$, but not $\mathrm{CD} 18^{-/-} \mathrm{CD} 62 \mathrm{P}^{-/-}$, mice generated by crossbreeding failed to thrive, reaching a maximum body weight of $10-15$ grams. To explore the mechanisms underlying reduced viability, we investigated lethally irradiated $C D 62 E^{-/-}$mice that were reconstituted with $C D 18^{-/-}$bone marrow. These mice, but not singlemutant controls, showed tenfold-increased rolling velocities in a TNF- $\alpha$-induced model of inflammation. Leukocyte adhesion efficiency in $C D 18^{-/-} C D 62 E^{-/-}$mice was reduced by $95 \%$, and hematopoiesis was drastically altered, including severe bone marrow and blood neutrophilia and elevated G-CSF and GM-CSF levels. The greatly reduced viability of $C D 18^{-/-} C D 62 E^{-/-}$mice appears to result from an inability to mount an adequate inflammatory response. Our data show that cooperation between E-selectin and CD18 integrins is necessary for neutrophil recruitment and that alternative adhesion pathways cannot compensate for the loss of these molecules.

J. Clin. Invest. 106:1457-1466 (2000).

\section{Introduction}

Leukocyte recruitment to sites of inflammation requires leukocyte capture, rolling, and adhesion on activated endothelial cells. Leukocyte recruitment has been viewed as a cascade of events occurring in separable, sequential steps that are dependent on different adhesion molecules. Leukocyte capture and rolling are largely mediated by selectins and their ligands $(1,2)$; firm adhesion and transmigration require $\beta_{2}$ integrins $(3,4)$. The $\beta_{2}$ integrins are heterodimeric molecules composed of an $\alpha$ chain (CD11a, b, c, or d) and a common $\beta$ chain (CD18). The development of various adhesion molecule-deficient mice has provided valuable information on the mechanisms of leukocyte recruitment.

The phenotypes of the different mice lacking one, two, or three selectins, one or all $\beta_{2}$ integrins, ICAM- 1 alone, and both ICAM-1 and P-selectin have been described previously (3, 5-20). E-selectin-deficient mice (CD62 $E^{-/-}$mice) show elevated leukocyte rolling velocities (5), increased leukocyte rolling flux (5), a reduced ability to produce adhesion in response to chemoattractants (21), and impairment of inflammatory function in at least three different models $(5,21,22)$. CD18null $\left(C D 18^{-/-}\right)$mice have severe defects in leukocyte recruitment, adhesion, and activation (3). In TNF$\alpha$-induced inflammation, leukocyte rolling velocities in $\mathrm{CD} 18^{-/-}$mice are significantly elevated, indicating that
CD18 integrins are involved in mediating leukocyte rolling (23). Leukocyte rolling velocities were increased even further, and the efficiency of leukocyte adherence was significantly decreased in $C D 18^{-/-}$mice that were given an antibody that blocks E-selectin function (23). These data suggest that the steps in leukocyte recruitment are not discrete, separable events, but that the functions of selectins and integrins overlap to mediate efficient leukocyte recruitment. Therefore, we hypothesized that mice deficient in both CD18 and E-selectin (CD18-/-CD62 $E^{-/-}$mice) would display a severe phenotype, due to an inability to recruit leukocytes to sites of injury and inflammation. To test this hypothesis, we generated $C D 18^{-/-} C D 62 E^{-/-}$double-mutant mice by crossbreeding. CD $18^{-/-} \mathrm{CD} 62 \mathrm{E}^{-/-}$mice demonstrated severely reduced viability. To obtain adult mice to investigate the inflammatory defect in $\mathrm{CD} 18^{-/-} \mathrm{CD} 62 \mathrm{E}^{-/-}$ mice, we generated mice lacking both CD18 and Eselectin by transplantation of $\mathrm{CD} 18^{-/-}$bone marrow into adult $C D 62 E^{-/-}$mice. This study describes the phenotype of these mice and provides a mechanistic explanation for the severe inflammatory defect and lethality.

\section{Methods}

Generation of $\mathrm{CD} 18^{-/-} \mathrm{CD} 62 \mathrm{E}^{-/-}$and $\mathrm{CD} 18^{-/-} \mathrm{CD} 62 \mathrm{P}^{-/-}$ mice. Mice deficient in both CD18 and E-selectin were generated by crossbreeding CD18 ${ }^{-/-}$C57BL/6 N6 (3) 
and $C D 62 E^{-/-}$C57BL/ 6 N6 (11) mutants. Homozygosity of the double mutations was confirmed by Southern analysis (data not shown). CD18 and P-selectin double-mutant mice were generated by crossbreeding CD18 ${ }^{-/-}$C57BL/6 N6 (3) and CD62P-/- C57BL/6 N6 (7) mutants. Homozygosity of the double mutants was confirmed by PCR (data not shown).

Bone marrow transplantation. CD18-null, Eselectin-null, and wild-type mice (Hilltop Lab Animals, Scottdale, Pennsylvania, USA) were maintained at the University of Virginia Health Sciences Center vivarium. All mice used in this study were backcrossed into the C57BL/ 6 background for at least six generations. Bone marrow transplant recipient mice were approximately 2-3 months of age.

Bone marrow was harvested from donor mice and transplanted into recipient mice as described previously (13). Briefly, recipient mice were lethally irradiated with two doses of $6 \mathrm{~Gy}$, each approximately 4 hours apart. Donor mice were sacrificed by lethal injection of sodium pentobarbital (Nembutal; Abbott Laboratories, North Chicago, Illinois, USA). Bone marrow cells from both femurs and tibias were harvested under sterile conditions. Approximately 50 million nucleated cells were obtained from each donor mouse. Bones were flushed with RPMI 1640 (without phenol red; Life Technologies Inc., Grand Island, New York, USA) containing 10\% FCS (Atlanta Biologicals, Norcross, Georgia, USA). Suspended bone marrow cells were washed, and erythrocytes were lysed in $0.15 \mathrm{M} \mathrm{NH}_{4} \mathrm{Cl}$ lysing solution. Approximately 1-2 million unfractionated bone marrow cells in $200 \mu \mathrm{l}$ of media were delivered intravenously through the tail vein of each recipient mouse. Recipient mice were housed in a barrier facility (individually ventilated cages, HEPA-filtered air) under pathogen-free conditions before and after bone marrow transplantation. After bone marrow transplantation, mice were maintained on autoclaved water with antibiotics $(5 \mathrm{mM}$ sulfamethoxazole and $0.86 \mathrm{mM}$ trimethoprim; Sigma Chemical Co., St. Louis, Missouri, USA) and were fed autoclaved food. These conditions were maintained for 4-5 weeks until intravital microscopy.

Intravital microscopy. Mice were anesthetized with an intraperitoneal injection of ketamine hydrochloride $(125 \mathrm{mg} / \mathrm{kg}$; Abbott Laboratories), xylazine (12.5 $\mathrm{mg} / \mathrm{kg}$; Vedco Inc., St. Joseph, Missouri, USA), and atropine $(0.25 \mathrm{mg} / \mathrm{kg}$; Elkins-Sinn Inc., Cherry Hill, New Jersey, USA). All mice in the $C D 18^{-/-} C D 62 E^{-/-}$ group, the $\mathrm{CD} 62 \mathrm{E}^{-/-}$group, and the wild-type group received bone morrow transplants as described above. Since data from mice transplanted with $\mathrm{CD} 18^{-/-}$marrow were indistinguishable from data obtained in CD1 $8^{-/-}$mice, the latter were used for intravital experiments. The trachea was intubated, and anesthetic (diluted sodium pentobarbital in saline) was administered throughout the intravital experiment through one cannulated jugular vein. Blood pressure was monitored, and blood samples were obtained through a cannulated carotid artery. Mice were kept at a constant temperature of $37^{\circ} \mathrm{C}$ with a thermocontrolled heating pad (Physitemp Instruments Inc., Clifton, New Jersey, USA) during the intravital microscopy experiment. The cremaster muscle was prepared for intravital microscopy as described (5). For the TNF- $\alpha$-induced model of inflammation, recombinant murine TNF- $\alpha$ (Genzyme Pharmaceuticals, Cambridge, Massachusetts, USA) was injected intrascrotally at a dose of 500 $\mathrm{ng}$ (in $0.3 \mathrm{ml}$ of sterile saline) per mouse, 2 hours before exteriorization of the cremaster muscle. The cremaster muscle was superfused with thermocontrolled $\left(35^{\circ} \mathrm{C}\right)$ bicarbonate-buffered saline. Throughout the experiment, blood samples were taken from the carotid catheter to analyze systemic leukocyte concentrations. Kimura-stained blood samples were analyzed using a hemocytometer to obtain leukocyte counts. Microscope observations were made with an intravital microscope (Axioskop; Carl Zeiss Inc., Thornwood, New York, USA) using a saline immersion objective (SW 40/0.75 numerical aperture). Venules with diameters between $20 \mu \mathrm{m}$ and $80 \mu \mathrm{m}$ were observed and recorded using a CCD camera system (model VE-1000 CCD; Dage-MTI Inc., Michigan City, Indiana, USA) on a Panasonic S-VHS recorder. Centerline red-blood-cell velocity was measured using a dual photodiode and a digital online cross-correlation program (24). Mean blood-flow velocities were obtained by multiplying the centerline velocity by an empirical factor of 0.625 (25). Wall shear rates $\left(\gamma_{\mathrm{w}}\right)$ were estimated as $2.12\left(8 V_{\mathrm{b}} / d\right)$, where $V_{\mathrm{b}}$ is the mean blood-flow velocity, $d$ is the diameter of the vessel, and 2.12 is a median empirical correction factor obtained from velocity profiles measured in microvessels in vivo (26).

Rolling and adhesion parameters. A digital image-processing system was used to measure microvessel diameters, lengths, and leukocyte rolling velocities (24). Leukocyte rolling flux, expressed as leukocytes per minute, was calculated by counting leukocytes rolling past a line set perpendicular to the vessel axis (27). Leukocyte rolling velocities were measured for ten leukocytes per venule. Adherent leukocytes were defined as leukocytes that did not move for at least 30 seconds. The total number of adherent leukocytes was determined for each venule segment $(\sim 200 \mu \mathrm{m})$, and was expressed per unit area (of inside surface area of the venule). For some graphs, the number of adherent leukocytes was normalized with the leukocyte rolling flux (adherent cells $/ \mathrm{mm}^{2}$ per 100 rolling cells/min) to obtain a parameter reflecting the efficiency of converting rolling leukocytes to firmly adherent leukocytes in each venule, as described previously (23).

Flow cytometry. Expression of CD18 on mouse neutrophils obtained from peripheral blood and bone marrow was determined by direct immunofluorescence. Bone marrow cells were harvested as described above using PBS (GIBCO BRL, Rockville, Maryland, USA) with $0.02 \%$ azide. Whole blood or bone marrow was incubated with FITC-labeled Gr-1 mAb (PharMingen, San Diego, California, USA; $0.5 \mu \mathrm{g} / 10^{6}$ cells) to identify granulocytes, and 
with phycoerythrin-labeled $\mathrm{mAb}$ C71/16 to label CD18 (PharMingen; $0.5 \mu \mathrm{g} / 10^{6}$ cells) or isotype control (R3595; PharMingen; $0.5 \mu \mathrm{g} / 10^{6}$ cells). Samples were incubated for 30 minutes on ice. Unlabeled antibody was removed by aspiration after centrifugation. Bone marrow cells were resuspended in PBS with $0.02 \%$ azide. Peripheral blood was resuspended in $150 \mathrm{mM} \mathrm{NH}_{4} \mathrm{Cl}, 10 \mathrm{mM}$ $\mathrm{NaHCO}_{3}$, and $1 \mathrm{mM} \mathrm{Na} 2 \mathrm{EDTA}$ in deionized, distilled water to lyse red blood cells. Cells were analyzed by forward scatter, side scatter, FITC fluorescence, and phycoerythrin fluorescence using a laser flow cytometer (FACScan; Becton Dickinson Immunocytometry Systems, San Jose, California, USA). Neutrophils were identified and gated by expression of Gr-1 antigen. Data are presented as fluorescence histograms of CD18 expression of Gr1-positive cells on a four-decade log scale.

Histology. To differentiate intravascular and interstitial leukocytes, cremaster muscle whole mounts were prepared as described previously (23). The Giemsastained cremaster muscles were observed using a Zeiss microscope with a $\times 100,1.4$ numerical aperture oil immersion objective (Carl Zeiss Inc., Jena, Germany). Intravascular and interstitial leukocytes were counted and differentiated into neutrophils, eosinophils, and mononuclear cells. The interstitial tissue observed was a circular area $(183 \mu \mathrm{m}$ in diameter) bisected by each venule. Other C57BL/ 6 wild-type mice, lethally irradiated wild-type mice transplanted with wild-type bone marrow, and lethally irradiated $C D 62 E^{-/-}$mice transplanted with $C D 18^{-/-}$bone marrow were sacrificed for histological analysis. Tissues were fixed in $10 \%$ buffered formalin (Sigma Chemical Co.), embedded in paraffin, and stained with hematoxylin and eosin.

Microbiological analyses. For bacterial cultures, samples of the lung, liver, spleen, and blood were obtained in a sterile manner from wild-type and $C D 18^{-/-} \mathrm{CD} 62 \mathrm{E}^{-/-}$ mice. Tissues were homogenized in a sterile glass grinder after the addition of $1 \mathrm{ml}$ of Luria Bertani broth (Life Technologies Inc.). Tissues were ground to homogeneity. A sample of the ground tissue was obtained with a sterile cotton-tipped swab that was used for the primary streak onto a trypticase soy agar plate with $5 \%$ sheep red blood cells (Difco Laboratories, Detroit, Michigan, USA). Colonies were removed and Gramstained for primary identification. Individual representative colonies from samples that were positive for growth were sent to the University of Virginia Hospital Clinical Microbiology Department for further identification using standard microbiological methods.

G-CSF and GM-CSF ELISA. Plasma G-CSF concentrations were measured using a specific enzyme-linked immunoassay as described previously (28). Murine recombinant G-CSF was generously provided by Amgen Inc. (Thousand Oaks, California, USA). G-CSF concentrations were calculated from a standard curve $(50-1,200 \mathrm{pg} / \mathrm{ml})$ using log-log linear regression. There was an interassay coefficient of vari- ation of $4.4 \%$. Specificity was tested, and the assay failed to detect $1,200 \mathrm{pg} / \mathrm{ml}$ of homologous mouse proteins (growth hormone and prolactin) or murine GM-CSF, IL-3, IL-6, or E. coli LPS. The sensitivity of the assay was $30 \mathrm{pg} / \mathrm{ml}$. Enzyme-linked immunoassay for GM-CSF was performed as suggested by the manufacturer (R\&D Systems Inc., Minneapolis, Minnesota, USA); sensitivity of the assay was $1 \mathrm{pg} / \mathrm{ml}$. Specificity was tested, and the assay failed to detect $50 \mathrm{ng} / \mathrm{ml}$ of G-CSF, IL-3, IL-6, or stem cell factor.

Myeloperoxidase activity. Myeloperoxidase (MPO) levels were measured in the lung and spleen using methods described previously $(29,30)$. Samples were homogenized $(1: 20 \mathrm{wt} / \mathrm{vol})$ in ice-cold $20 \mathrm{mM} \mathrm{KPO}_{4}$ buffer (pH 7.4) and centrifuged at $17,000 \mathrm{~g}\left(4^{\circ} \mathrm{C}\right.$ for $30 \mathrm{~min}-$ utes). Pellets were resuspended in ice-cold $20 \mathrm{mM} \mathrm{KPO}_{4}$ buffer ( $\mathrm{pH}$ 7.4) and centrifuged at $17,000 \mathrm{~g}$ for $30 \mathrm{~min}-$ utes twice. The final pellet was resuspended in $0.5 \%$ (wt/vol) hexadecyltrimethylammonium bromide and $10 \mathrm{mM}$ EDTA in $50 \mathrm{mM} \mathrm{KPO}_{4}$ (pH 6.0) $(250 \mu \mathrm{l}$ of buffer per $1 \mathrm{ml}$ of original homogenized pellet suspension). Suspensions were sonicated on ice for 1 second, five times; subjected to three freeze-thaw cycles; and then incubated for 20 minutes at $4^{\circ} \mathrm{C}$. The final suspensions were centrifuged at $17,000 \mathrm{~g}$ for 15 minutes at $4^{\circ} \mathrm{C}$, and supernatants were analyzed for MPO activity. Assay buffer $(0.2 \mathrm{mg} / \mathrm{ml} o$-dianisidine and $158 \mu \mathrm{M}$ $\mathrm{H}_{2} \mathrm{O}_{2}$ in $50 \mathrm{mM} \mathrm{KPO}_{4}$, $\mathrm{pH}$ 6.0) was added to the supernatant at a ratio of $4: 1$, in triplicates. Changes in absorbance were recorded at $460 \mathrm{~nm}$ over 5 minutes. The linear part of the resulting curve was used for calculating MPO activity. One unit of activity is defined as a change in absorbance of 1.0 per minute at $25^{\circ} \mathrm{C}$. Results were expressed as units of MPO per mg of protein as determined by bicinchoninic acid assay (Pierce Chemical Co., Rockford, Illinois, USA).

Hematopoietic colony formation assay. Femurs and tibias from wild-type mice and $C D 18^{-/-} C D 62 E^{-/-}$mice were flushed with BIT 9500 (StemCell Technologies Inc., Vancouver, British Columbia, Canada). Bone marrow cells were added to MethoCult GF M3434 (StemCell Technologies Inc.) at a ratio of 1:10 (vol/vol). Cells were plated at a density of 50,000 and 100,000 cells per dish in duplicate assays. GM-CFU and burst-forming unit-ery-

Table 1

Systemic neutrophil counts, spleen weights, and tissue neutrophil infiltration

\begin{tabular}{|c|c|c|c|c|}
\hline & \multirow{2}{*}{$\begin{array}{l}\text { Systemic } \\
\text { neutrophil } \\
\text { count } \\
(\text { cells } / \mu \mathrm{l})\end{array}$} & \multirow[b]{2}{*}{$\begin{array}{c}\text { Spleen } \\
\text { weight }(\mathrm{mg})\end{array}$} & \multicolumn{2}{|c|}{$\begin{array}{l}\text { MPO } \\
\text { Absorbance/protein } \\
\text { concentration } \\
(\mathrm{mU} / \mathrm{mg})\end{array}$} \\
\hline & & & Spleen & Lung \\
\hline & $1,320 \pm 355$ & $96 \pm 4$ & $132 \pm 27$ & $69 \pm 14$ \\
\hline & $1,525 \pm 136$ & $106 \pm 6$ & $109 \pm 6$ & $65 \pm 6$ \\
\hline$C D 18^{-/-}$ & $61,280 \pm 21,623^{A}$ & A $339 \pm 55^{A}$ & $1,727 \pm 208^{A}$ & $603 \pm 93^{A}$ \\
\hline$C D 18^{-/-}$CD $62 E^{-/-}$ & $72,633 \pm 22,388^{A}$ & A $286 \pm 21^{A}$ & $1,380 \pm 260^{A}$ & $836 \pm 151^{A}$ \\
\hline
\end{tabular}

One unit of MPO activity is defined as a change in absorbance of 1.0 per minute at $25^{\circ} \mathrm{C}$. Data expressed as mean \pm SEM. ASignificantly different from wild-type and $C D 62 E^{-1}$ groups $(P<0.05)$. 


\section{Figure 1}

Mice deficient in CD18 integrins and E-selectin fail to thrive. CD18-/-CD62E-/- double-mutant mice are runted at birth and require constant care for survival. A typical CD18-/-CD62E ${ }^{-/-}$mutant (left) is shown with a $C D 18^{+/+} C D 62 E^{-/-}$littermate at 12 days of age. The double mutant was significantly smaller $(2.0 \mathrm{~g})$ than its littermate $(5.7 \mathrm{~g})$.

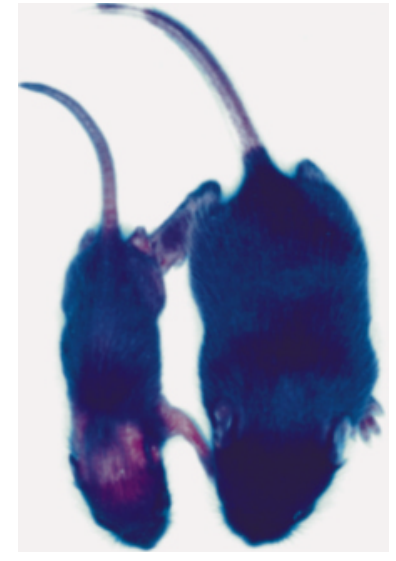

throcyte colony formation was counted on day 7.

Statistics. Average leukocyte rolling velocities, leukocyte adhesion, systemic leukocyte counts, and differentials between groups were compared using one-way ANOVA and the Kruskal-Wallis multiple comparison test. Statistical significance was set at $P<0.05$.

\section{Results}

Phenotype of CD18 $18^{-/-} \mathrm{CD} 62 \mathrm{E}^{-/-}$and $\mathrm{CD} 18^{-/-} \mathrm{CD} 62 \mathrm{P}^{-/-}$mice. Mice deficient in CD18 and E-selectin (CD18 ${ }^{-/-} \mathrm{CD} 62 \mathrm{E}^{-/}$ mice) were generated by interbreeding $\mathrm{CD} 18$ and $\mathrm{E}-$ selectin single mutants. $C D 18^{-/-} \mathrm{CD} 62 \mathrm{E}^{-/-}$mutants from $C D 18^{+/-} C D 62 E^{-/-}$breeders were born at the expected Mendelian ratios ( 8 mutants of 30 mice, $P=$ not significant), providing no evidence for in utero lethality. $\mathrm{CD} 18^{-/-} \mathrm{CD} 62 \mathrm{E}^{-/-}$mice that survived to weaning were runted compared with littermates (Figure 1). They failed to thrive, reaching maximum body weights of 10-15 grams. $C D 18^{-/-} C D 62 E^{-/-}$mice required constant care for survival, including cutting of teeth and being given crushed food and antibiotics. Accurate survival curves could not be obtained because sick mice were killed in accordance with IACUC procedures. Most of the $\mathrm{CD} 18^{-/-} \mathrm{CD} 62 \mathrm{E}^{-/-}$mice that survived to 6 weeks of age developed mucocutaneous skin lesions and overgrowth of the incisors. They failed to breed and had reduced viability.

In contrast, $C D 18^{-/-} C D 62 P^{-/-}$mice generated by interbreeding single mutants were indistinguishable from littermates. $\mathrm{CD} 18^{-/-} \mathrm{CD} 62 \mathrm{P}^{-/-}$mice showed no differences in body weights at birth or at weaning compared with littermates. $\mathrm{CD} 18^{-/-} \mathrm{CD} 62 \mathrm{P}^{-/-}$mice did not have weaning weights that differed from controls $\left(C D 18^{+/-} \mathrm{CD} 62 \mathrm{P}^{+/-}\right)$ $(11.3 \pm 1.3 \mathrm{~g}$ and $12.1 \pm 1.6 \mathrm{~g}$, respectively; mean $\pm \mathrm{SD})$. $\mathrm{CD} 18^{-/-} \mathrm{CD} 62 \mathrm{P}^{-/-}$mice survived to adulthood (> 90\% over 3 months) and bred successfully.

Since CD18 is exclusively expressed on bone marrow-derived blood cells, and E-selectin is restricted to endothelial cells, mice deficient in CD18 and E-selectin were generated by transplanting lethally irradiated $C D 62 E^{-/-}$mice with $C D 18^{-/-}$bone marrow. As controls, wild-type, $C D 62 E^{-1-}$, and $C D 18^{-/-}$mice were also generated through the appropriate bone marrow transplantation. All nontransplanted mice died within 2 weeks of irradiation (1.2 Gy). Despite residing in a pathogenfree barrier facility, approximately $50 \%$ of the $\mathrm{CD} 18^{-/-} \mathrm{CD} 62 \mathrm{E}^{-/-}$mice generated by bone marrow transplantation died within a few weeks of transplantation, compared with less than $5 \%$ for wild-type, $\mathrm{CD} 18^{-/-}$, and $\mathrm{CD} 62 \mathrm{E}^{-/-}$mice. $\mathrm{CD} 18^{-/-} \mathrm{CD} 62 \mathrm{E}^{-/-}$doublemutant mice became progressively sick, resulting in chronic ulcerative dermatitis and significant weight loss (body weights less than 20 grams, reduced from 25 grams at the time of transplantation). Circulating neutrophil counts in $\mathrm{CD} 18^{-/-} \mathrm{CD} 62 \mathrm{E}^{-/-}$mice became increasingly elevated as a function of time after transplantation (reaching 50,000-150,000/ $\mu \mathrm{l}$ ).

Four weeks after reconstitution, peripheral blood and bone marrow of chimeric mice were analyzed for CD18 expression (Figure 2). CD18 expression was undetectable on bone marrow and blood cells in mice transplanted with $C D 18^{-/-}$bone marrow, confirming that reconstitution was efficient and complete.

Histopathology. $C D 18^{-/-} \mathrm{CD} 62 \mathrm{E}^{-/-}$mice showed moderate to severe ulcerative dermatitis similar to that of CD18 $18^{-/}$mice (3). Histopathology of the skin revealed significant hyperplasia of the epithelium, hyperkeratosis, acute ulceration with bacterial colonies under the ulcer, mild lymphocytic and neutrophilic infiltration throughout the dermis, and a thickened dermis (Figure 3a). Gram-stained histologic sections of CD18 $18^{-/-} \mathrm{CD} 62 E^{-/-}$mice showed Gram-positive cocci (Figure 3b). Gram staining of the wild-type skin sections showed no evidence of organisms (data not shown). Bacterial cultures of the lung, liver, spleen, and
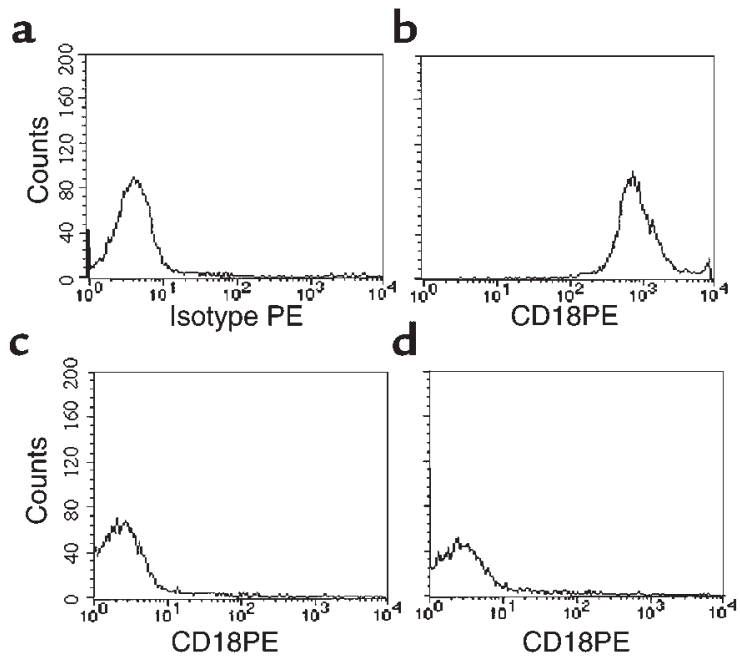

Figure 2

Expression of CD18 (mAb C71/16) on unfractionated bone marrow cells 4 weeks after reconstitution. Neutrophils were identified and gated for expression of $\mathrm{Gr}-1$ antigen. (a) Isotype control. Irradiated wild-type mice transplanted with wild-type bone marrow expressed high levels of CD18 (b). Transplantation of CD18-/- mouse bone marrow into irradiated wild-type mice (c) and irradiated $C D 62 E^{-/-}$ mice $(\mathbf{d})$ resulted in a complete absence of CD18 expression on all bone marrow and blood cells. 
blood of six CD18-/-CD62 $E^{-/-}$mice showed one spleen positive for a Corynebacterium species. None of the four wild-type mice showed positive cultures in any organs. $\mathrm{CD} 18^{-/-} \mathrm{CD} 62 \mathrm{E}^{-/-}$mice also displayed splenomegaly, with an approximately threefold increase in spleen weight due to myeloid hyperplasia within the red pulp consisting of primitive, intermediate, and differentiated cells. Myeloid hyperplasia was also present in the bone marrow of $C D 18^{-/-} \mathrm{CD} 62 \mathrm{E}^{-/-}$mice.

To quantify neutrophil content in the spleen, $\mathrm{MPO}$ levels were measured in wild-type, $C D 62 E^{-/-}, C D 18^{-/-}$, and $C D 18^{-/-} C D 62 E^{-/-}$mice. Spleen weights were increased threefold in $\mathrm{CD} 18^{-/-}$and $\mathrm{CD} 18^{-/-} \mathrm{CD} 62 \mathrm{E}^{-/-}$mice compared with $C D 62 E^{-/-}$and wild-type mice (Table 1). Consistent with extramedullary hematopoiesis, a drastic increase in MPO activity was observed in the spleen of $\mathrm{CD} 18^{-/-}$and $\mathrm{CD} 18^{-/-} \mathrm{CD} 62 \mathrm{E}^{-/-}$mice compared with wildtype and $C D 62 E^{-/-}$mice (Table 1 ). In addition, neutrophil content in the lungs was elevated in the $C D 18^{-/-}$ and $C D 18^{-/-} C D 62 E^{-/-}$mice (Table 1 ), suggesting abnormal neutrophil trafficking and margination.

Analysis of hematopoiesis in $\mathrm{CD} 18^{-/-} \mathrm{CD} 62 \mathrm{E}^{-/-}$mice. Consistent with the highly elevated level of neutrophils in the peripheral blood, a morphological analysis of stained bone marrow cytospins showed a drastic increase in the percentage of neutrophils and neutrophil precursors compared with wild-type mice (data not shown). Unfractionated bone marrow and peripheral blood were analyzed for expression of the myeloid marker Gr-1 (31) using flow cytometry (Figure 4, a and $\mathrm{b}$, respectively). $\mathrm{CD} 18^{-/-}$mice showed an increase in bone marrow Gr-1 expression of approximately $75 \%$, compared with approximately $50 \%$ in wild-type and $C D 62 E^{-/-}$mice (Figure 4a). Remarkably, the percentage of Gr-1-expressing cells in the bone marrow and blood of $C D 18^{-/-} C D 62 E^{-/-}$mice exceeded $90 \%$ (Figure 4 , a and b). In vitro hematopoietic progenitor colony assays showed no increase in GM-CFU colony formation at day 7 in $C D 18^{-/-} C D 62 E^{-/-}$mice compared with wildtype mice (data not shown).

Serum G-CSF and GM-CSF levels. G-CSF levels in wildtype, $C D 62 E^{-/-}, C D 18^{-/-}$, and $C D 18^{-/-} C D 62 E^{-/-}$mice were measured to investigate the possible role of G-CSF in mediating the significant overproduction of neutrophils. Peripheral blood neutrophil counts were significantly elevated in $\mathrm{CD} 18^{-/-}$and $\mathrm{CD} 18^{-/-} \mathrm{CD} 62 \mathrm{E}^{-/-}$ mice. Serum G-CSF levels in $C D 18^{-/-} \mathrm{CD} 62 E^{-/-}$mice were significantly higher $(304 \pm 75 \mathrm{pg} / \mathrm{ml})$ than in wildtype, $C D 62 E^{-1-}$, and $C D 18^{-1-}$ mice (none detected) (Figure $4 \mathrm{c}$ ), indicating that G-CSF may mediate the neutrophilia observed in $C D 18^{-/-} \mathrm{CD} 62 \mathrm{E}^{-/-}$mice. To determine the possible involvement of GM-CSF in the neutrophilia, GM-CSF serum levels were also measured. GM-CSF was elevated in $C D 18^{-/-} \mathrm{CD} 62 \mathrm{E}^{-/-}$mice $(2.1 \pm 1.2 \mathrm{pg} / \mathrm{ml})$ compared with wild-type, $C D 62 E^{-/-}$, and $C D 18^{-/-}$mice (none detected) (Figure $4 \mathrm{~d}$ ).

Intravital microscopy. Leukocyte rolling and adhesion were investigated in wild-type, $C D 62 E^{-/-}, C D 18^{-/-}$, and $\mathrm{CD} 18^{-/-} \mathrm{CD} 62 \mathrm{E}^{-/-}$mice in the cremaster muscle 2 hours after injection of TNF- $\alpha$. During anesthesia and surgery in preparation for intravital microscopy experiments performed at 4 weeks after transplantation, all $C D 18^{-/-} \mathrm{CD} 62 \mathrm{E}^{-/-}$mice weighing less than 20 grams died, and were not used for experiments. Therefore, the $C D 18^{-/-} \mathrm{CD} 62 \mathrm{E}^{-/-}$mice used for intravital microscopy probably represent a subgroup of healthier mice. Leukocyte rolling and adhesion were studied in hemo-
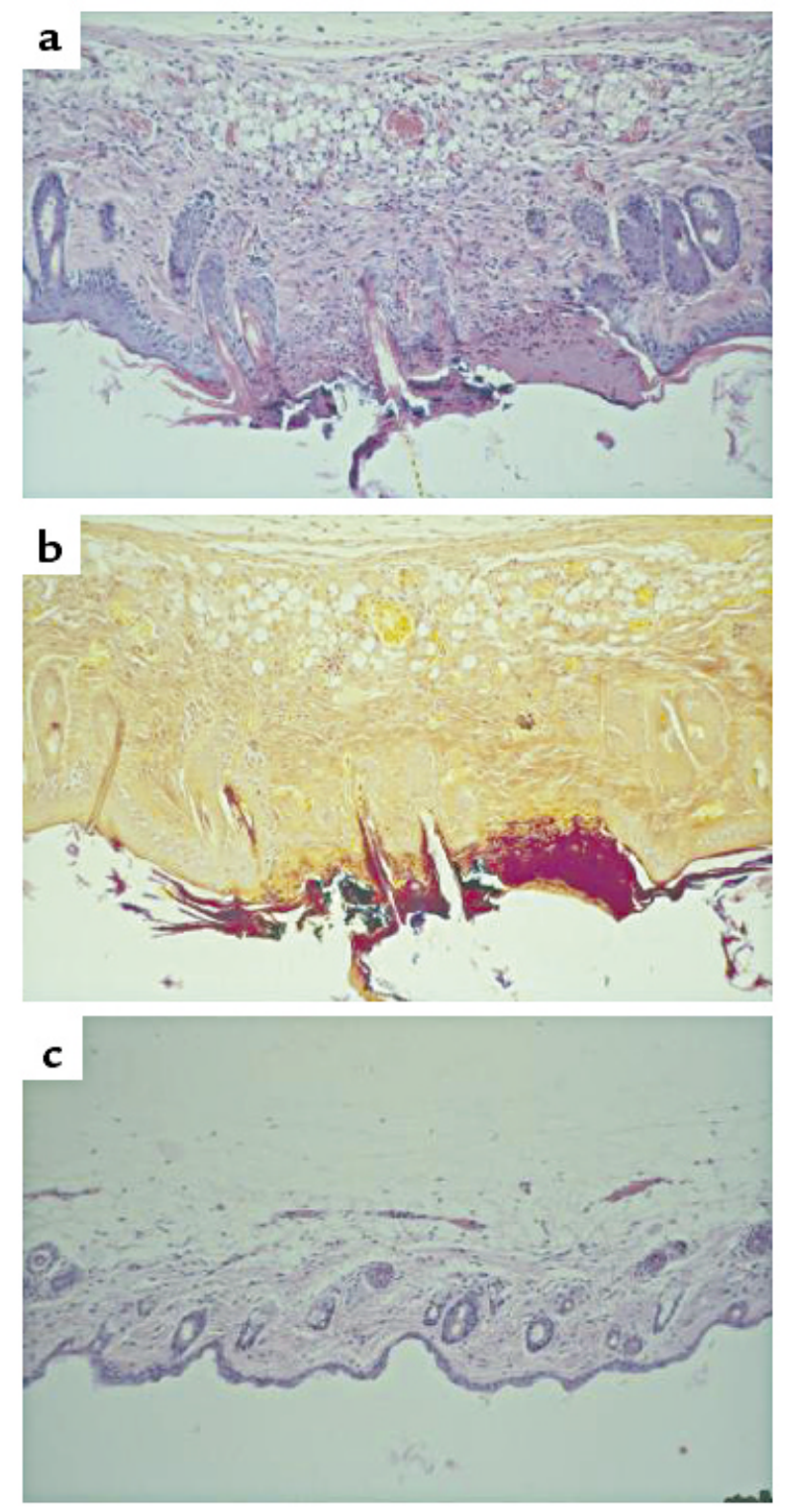

Figure 3

(a) Skin section from the facial area of a CD18 ${ }^{-/-} C D 62 E^{-/-}$mouse generated through bone marrow transplantation, stained with hematoxylin and eosin. Section shows hyperplasia of the epithelium, hyperkeratosis, acute ulceration with bacterial colonies in the ulcer, mild lymphocytic and neutrophilic infiltration throughout the dermis, and a thickened dermis. (b) Gram stain of histologic section from the $C D 18^{-/-} C D 62 E^{-/-}$ mouse in a showed Gram-positive cocci (dark staining pattern) and a coagulum of necrotic epithelium and exudate (dark red staining). (c) Skin section from the face of a C57BL/ 6 control mouse generated by bone marrow transplantation, stained with hematoxylin and eosin. Original magnification, $30 \times$. 


\section{Figure 4}

Expression of Gr-1 antigen on unfractionated bone marrow cells (a) and peripheral blood leukocytes (b). Gr-1 expression in CD18 $8^{-/-}$mice and $C D 18^{-/-} \mathrm{CD} 62 \mathrm{E}^{-/-}$mice is dramatically elevated (percent of cells expressing Gr-1 indicated; gate set to exclude $95 \%$ of cells stained with isotype control, not shown). (c) Concentration of G-CSF and (d) GM-CSF in plasma as measured by ELISA. Data expressed as mean \pm SEM.

a
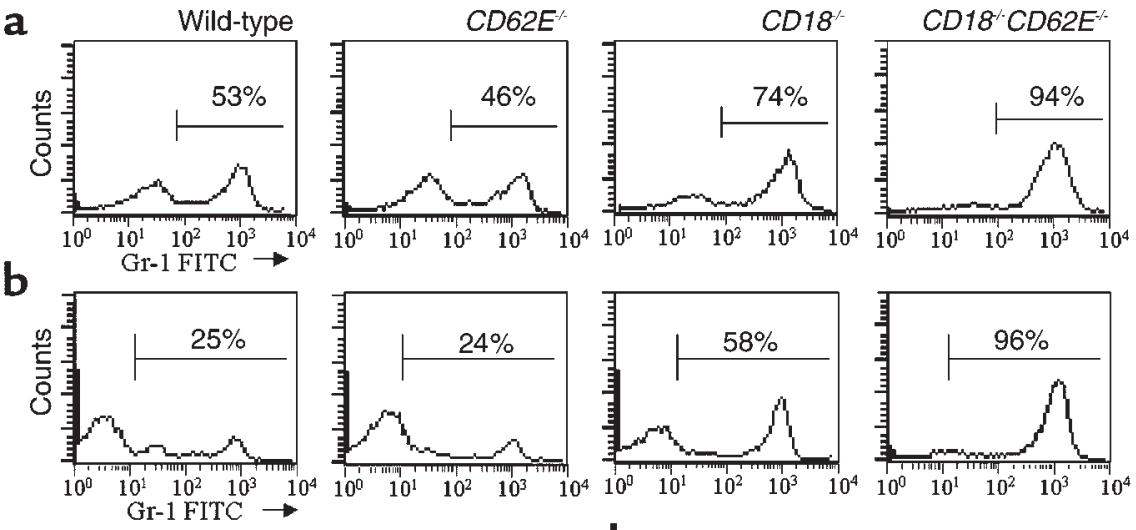

c
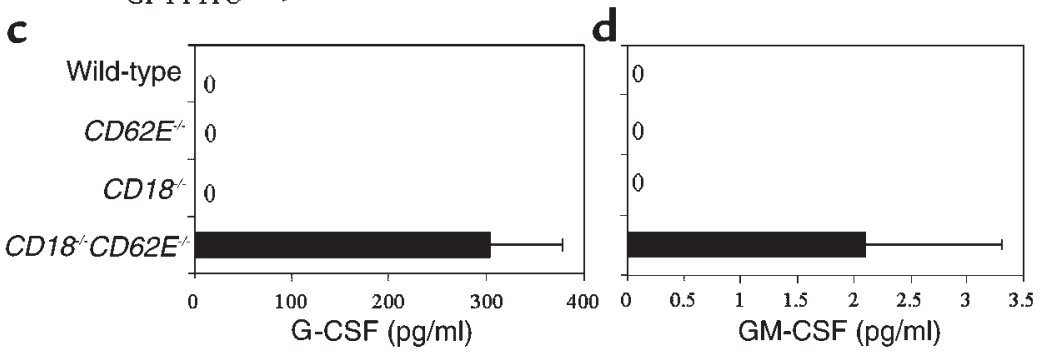

dynamically similar venules over a shear-rate range from $100 \mathrm{~s}^{-1}$ to approximately $1500 \mathrm{~s}^{-1}$ (Table 2).

TNF- $\alpha$ induces the expression of E-selectin and enhances the expression of P-selectin in mouse cremaster muscle venules (32). To determine if CD18 and Eselectin cooperatively mediate efficient slow leukocyte rolling, leukocyte rolling velocities were measured in wild-type, $C D 62 E^{-/-}, C D 18^{-/-}$, and $C D 18^{-/-} \mathrm{CD} 62 \mathrm{E}^{-/-}$mice. The majority of leukocytes rolled at velocities under 5 $\mu \mathrm{m} / \mathrm{s}$ in wild-type mice, resulting in an average leukocyte rolling velocity of $6.9 \pm 0.2 \mu \mathrm{m} / \mathrm{s}$ (Figure 5). A noticeable shift in the leukocyte rolling velocity distribution (peak at $10-15 \mu \mathrm{m} / \mathrm{s}$ ) and an increase in the average rolling velocity $(21.1 \pm 0.5 \mu \mathrm{m} / \mathrm{s})$ occurred in $C D 62 E^{-/-}$mice (Figure 5). Leukocyte rolling under $5.0 \mu \mathrm{m} / \mathrm{s}$ in $C D 62 E^{-1-}$ mice was very rare (1.6\% of rolling leukocytes, compared with $50.2 \%$ in wild-type mice), confirming that E-selectin is necessary for slow leukocyte rolling (5). The average rolling velocity in $C D 18^{-/-}$mice was increased to $22.7 \pm$ $0.8 \mu \mathrm{m} / \mathrm{s}$, due to a broadened rolling velocity distribution (leukocyte rolling velocities up to $\sim 100 \mu \mathrm{m} / \mathrm{s}$; Figure 5). A further dramatic broadening of the rolling velocity distribution occurred in the $\mathrm{CD} 18^{-/-} \mathrm{CD} 62 \mathrm{E}^{-/-}$ mice (Figure 5). Very few leukocytes rolled slower than $10 \mu \mathrm{m} / \mathrm{s}$, but a large population rolled faster than 50

Table 2

Hemodynamic data

\begin{tabular}{|c|c|c|c|c|}
\hline & $\begin{array}{l}\text { Wild- } \\
\text { type }\end{array}$ & $C D 62 E^{-/-}$ & CD18 & $\begin{array}{l}\text { CD18 } 8^{-/-} \\
\text {CD62E-/- }\end{array}$ \\
\hline Number of mice & 6 & 5 & 4 & 7 \\
\hline Number of venules & 68 & 58 & 47 & 57 \\
\hline Average venule diameter $(\mu \mathrm{m})$ & $47 \pm 2$ & $37 \pm 1$ & $43 \pm 2$ & $51 \pm 2$ \\
\hline Average wall shear rate $\left(\mathrm{s}^{-1}\right)$ & $470 \pm 30$ & $600 \pm 40$ & $460 \pm 30$ & $580 \pm 50$ \\
\hline
\end{tabular}

$\mu \mathrm{m} / \mathrm{s}(36 \%)$, shifting the rolling velocity distribution peak to $15-20 \mu \mathrm{m} / \mathrm{s}$. The average rolling velocity was $50.1 \pm 1.4 \mu \mathrm{m} / \mathrm{s}$ in $C D 18^{-/-} C D 62 E^{-/-}$mice, which was significantly higher than in either of the single mutants. These findings show that CD18 and E-selectin work cooperatively to efficiently mediate slow leukocyte rolling in TNF- $\alpha$-treated venules.

In many systems, leukocyte rolling has been reported to be influenced by wall shear rate $(33,34)$. Therefore, we stratified the venules into low, intermediate, and high shear-rate groups $\left(100-400 \mathrm{~s}^{-1}, 400-700 \mathrm{~s}^{-1}\right.$, and

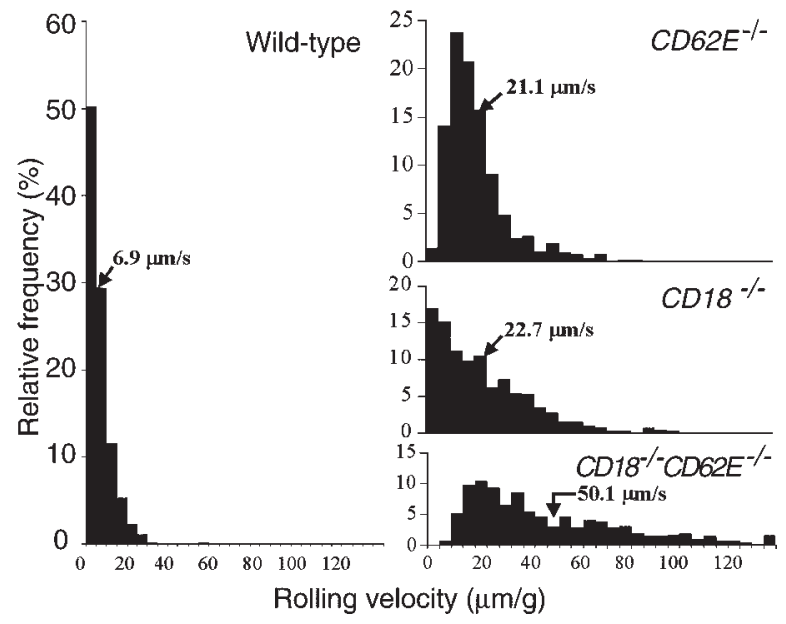

Figure 5

Leukocyte rolling velocity distributions in TNF- $\alpha$-treated cremaster muscle venules of wild-type, CD62 $E^{-/-}, C D 18^{-/-}$, and CD18 $18^{-/-} \mathrm{CD} 62 \mathrm{E}^{-/-}$mice. Arrowheads indicate mean leukocyte rolling velocity. All leukocytes rolling at velocities over $140 \mu \mathrm{m} / \mathrm{s}$ are represented by last bar. Leukocyte rolling velocities in wild-type mice and $C D 18^{-/-} C D 62 E^{-/-}$mice were significantly different from those in other groups $(P<0.05)$. 


\section{Figure 6}

Effect of shear rate on leukocyte rolling velocity distributions in TNF- $\alpha$-treated cremaster muscle venules of wild-type, CD62 $E^{-/-}, C D 18^{-/-}$, and CD18 $18^{-1-}$ CD $62 E^{-/-}$mice. Cumulative frequency curves of leukocyte rolling velocities in shear-rate ranges of $100-400 \mathrm{~s}^{-1}$ (thin dotted line), 400-700 s-1 (thin solid line), and $700-1500 \mathrm{~s}^{-1}$ (thick solid line). All leukocytes rolling at velocities over $140 \mu \mathrm{m} / \mathrm{s}$ are represented by last data point. Median rolling velocity for each shear-rate range is indicated by vertical lines. Inset shows rolling velocities of three leukocytes rolling over a $200-\mu \mathrm{m}$ distance in a venule of a wildtype mouse (closed circles, wall shear rate $754 \mathrm{~s}^{-1}$ ) and of three leukocytes rolling in a $C D 18^{-/-} C D 62 E^{-/-}$ mouse (open circles, wall shear rate $729 \mathrm{~s}^{-1}$ ).

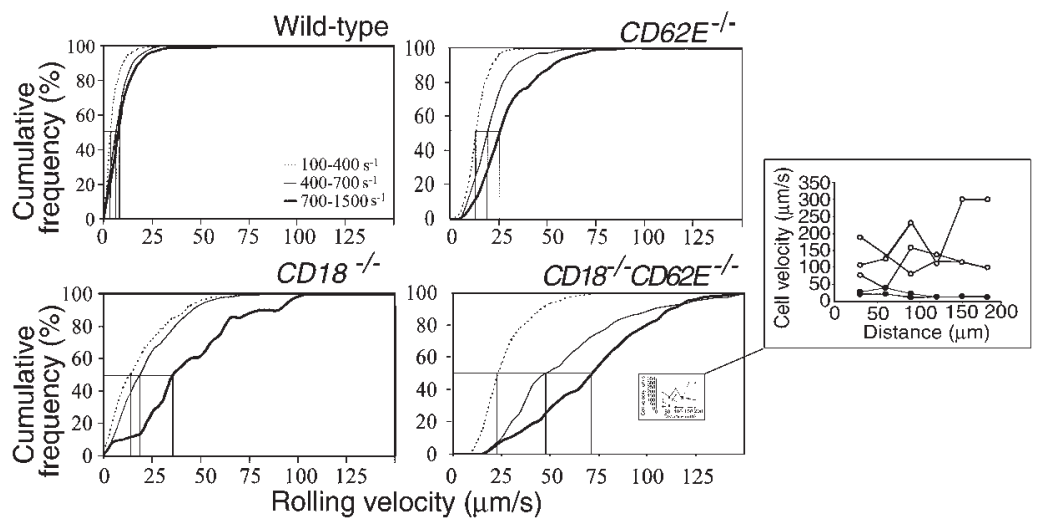

$\left.700-1500 \mathrm{~s}^{-1}\right)$. Rolling velocity distributions changed little in wild-type mice as the shear rate was increased (Figure 6). Increasing the shear rate in $C D 62 E^{-/-}$mice produced a noticeable shift in the rolling velocity distribution (Figure 6). A similar shift occurred in the low and medium shear-rate ranges in $\mathrm{CD}^{-18^{--}}$mice, as did a broadening of the velocity distribution, as reflected by the decreased slope of the cumulative rolling velocity histograms. A more drastic shift and broadening in rolling velocity distribution was seen in the high shearrate range in $\mathrm{CD} 18^{-/-}$mice. In $\mathrm{CD} 18^{-/-} \mathrm{CD} 62 \mathrm{E}^{-/-}$mice, rolling velocity was dramatically elevated over all shear rates (Figure 6). Leukocyte rolling became very unstable in $C D 18^{-/-} \mathrm{CD} 62 \mathrm{E}^{-/-}$at high shear rates. The leukocytes no longer rolled uniformly on the venule surface, but generally skipped along the surface, indicating repetitive capture and detachment events (inset in Figure 6). By contrast, leukocytes in wild-type mice showed slow, steady rolling at high wall shear rates. Table 3 summarizes the average leukocyte rolling velocities measured in the three shear-rate ranges. In all cases, the increase in average leukocyte rolling velocity in $\mathrm{CD} 18^{-/-} \mathrm{CD} 62 \mathrm{E}^{-/-}$ mice was approximately additive of the increases seen in $\mathrm{CD} 18^{-/-}$and $\mathrm{CD} 62 \mathrm{E}^{-/-}$mice.

The ability of rolling leukocytes to adhere to TNF$\alpha$-stimulated endothelium was studied to determine if leukocyte rolling velocity is an important parameter mediating efficient leukocyte recruitment. Consistent with highly elevated systemic counts, the leukocyte rolling flux was greatly enhanced in $\mathrm{CD}_{18^{-/}}$and $\mathrm{CD} 18^{-/-} \mathrm{CD} 62 \mathrm{E}^{-/-}$mice (Figure $\left.7 \mathrm{a}\right)$. To show how efficiently rolling leukocytes became firmly adhered, leukocyte adhesion was normalized for leukocyte rolling flux (Figure 7b). In $C D 18^{-/-} C D 62 E^{-/-}$double-mutant mice, 95\% fewer leukocytes became adherent per 100 rolling leukocytes than in wild-type mice (199 \pm 42 compared with 3,190 \pm 423 in wild-type mice; 1,269 \pm 448 in CD $62 E^{-/-}$mice; and $1,099 \pm 218$ in $C D 18^{-/-}$mice).

Next, we tested the correlation between leukocyte rolling velocity and the ability of rolling leukocytes to become adherent (Figure 8). Leukocyte adhesion efficiency was significantly reduced in each mouse type as the leukocyte rolling velocity increased due to increased shear rate. Within each shear-rate class, firm leukocyte adhesion was modestly reduced by the absence of Eselectin or CD18, and was drastically reduced in $C D 18^{-/-} \mathrm{CD} 62 E^{-/-}$mice. The lack of firmly adherent leukocytes in $\mathrm{CD} 18^{-/-} \mathrm{CD} 62 \mathrm{E}^{-/-}$mice correlated with the highly elevated leukocyte rolling velocities in all three shear-rate classes. Adhesion efficiency was most severely affected when leukocyte rolling velocity exceeded approximately $20 \mu \mathrm{m} / \mathrm{s}$, and when transit times fell below about 5 seconds for a $100-\mu \mathrm{m}$ segment of venule.

Giemsa-stained cremaster whole mounts were used to differentiate intravascular and transmigrated leukocytes (Figure 9, a-d). We found a remarkable impairment in the ability of neutrophils to interact successfully with the vessel wall in $C D 18^{-/-} \mathrm{CD} 62 \mathrm{E}^{-/-}$mice. Intravascular (rolling and firmly adhered) and transmigrated neutrophils were reduced by $80 \%$ in $C D 18^{-/-} C D 62 E^{-/-}$mice (Figure 9h) compared with wild-type, $C D 62 E^{-/-}$, and CD18 $8^{-/-}$mice (Figure 9, e-g). No other adhesion molecule-mutant mouse demonstrated a comparable reduction of neutrophil recruitment in this assay.

\section{Discussion}

Our data show that mice lacking both CD18 integrins and E-selectin have severely impaired viability. When adult animals are generated by bone marrow transplantation, they show the most severe inflammatory defect seen in any adhesion molecule-deficient mouse described to date. Their inability to recruit neutrophils to sites of inflammation results in high systemic neutrophil counts, which appear to be maintained through

\section{Table 3}

Average leukocyte rolling velocities $(\mu \mathrm{m} / \mathrm{s})$

\begin{tabular}{lrrr}
\hline \multicolumn{3}{c}{ Shear-rate range } \\
& $100-400 \mathrm{~s}^{-1}$ & $400-700 \mathrm{~s}^{-1}$ & $700-1500 \mathrm{~s}^{-1}$ \\
Wild type & $4.8 \pm 0.2^{\mathrm{A}}$ & $7.7 \pm 0.3^{\mathrm{A}}$ & $9.5 \pm 0.7^{\mathrm{A}}$ \\
CD62 $2 E^{-/-}$ & $13.5 \pm 0.4^{\mathrm{B}, \mathrm{C}}$ & $20.7 \pm 0.7^{\mathrm{B}, \mathrm{C}}$ & $29.0 \pm 1.3^{\mathrm{A}}$ \\
CD18 & $17.9 \pm 1.0^{\mathrm{B}, \mathrm{C}}$ & $22.6 \pm 1.1^{\mathrm{B}, \mathrm{C}}$ & $42.6 \pm 3.3^{\mathrm{A}}$ \\
CD18 $18^{-/-} C D 62 E^{-/-}$ & $26.7 \pm 0.9^{\mathrm{A}}$ & $57.7 \pm 2.2^{\mathrm{A}}$ & $71.4 \pm 2.6^{\mathrm{A}}$
\end{tabular}

All values expressed as mean \pm SEM. ASignificantly different from all other groups. ${ }^{B}$ Significantly different from wild type. CSignificantly different from CD $18^{-1-}$ CD $62 E^{-1-} . P<0.05$. 


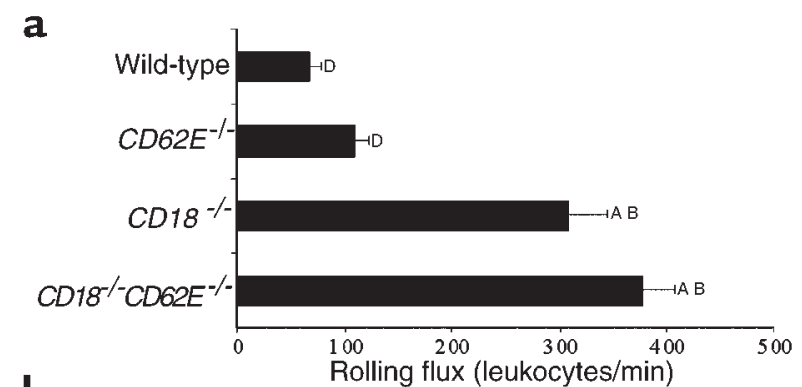

b

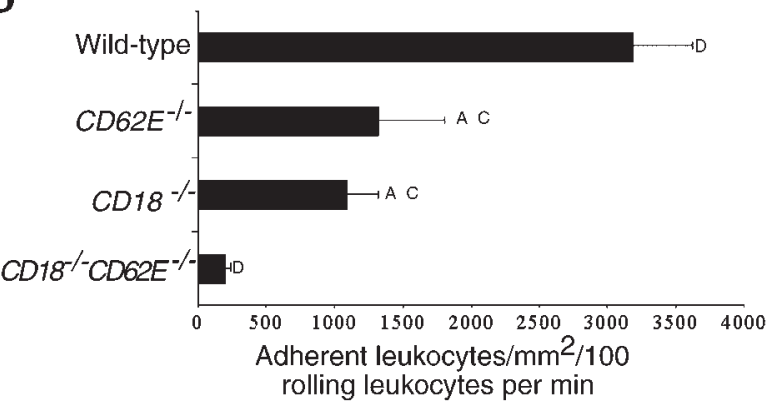

\section{Figure 7}

Leukocyte rolling and adhesion in TNF- $\alpha$-treated cremaster muscle venules of wild-type, $C D 62 E^{-/-}, C D 18^{-/-}$, and $C D 18^{-/-} C D 62 E^{-/-}$mice. (a) Leukocyte rolling flux (number of rolling cells/min). (b) Adhesion efficiency (adherent cells $/ \mathrm{mm}^{2}$ per 100 rolling cells $/ \mathrm{min}$ ). Data represented as mean \pm SEM, derived from 47-68 venules. ASignificantly different from wild type. ${ }^{B}$ Significantly different from $C D 62 E^{-1-}$. ${ }^{C S}$ ignificantly different from $C D 18^{-/-} C D 62 E^{-/-}$. DSignificantly different from all other groups $(P<0.05)$.

elevated levels of G-CSF (a key regulator of neutrophil production) and GM-CSF. Using intravital microscopy, we were able to show a strong inverse relationship between the velocity of rolling leukocytes and the efficiency of adhesion.

Based on the phenotypes of the CD18 and E-selectin single-mutant mice, it could not be expected that the double mutation would result in severely reduced viability. In the first publication to characterize Eselectin-null mice, the mice were described as lacking a clear inflammatory phenotype (9), although defects in leukocyte rolling (5) and adhesion (21), and increased susceptibility to Streptococcus pneumoniae (22) were described later. $C D 18^{-/}$mice develop skin ulcerations and have elevated neutrophil counts and immunoglobulin levels, increased susceptibility to $S$. pneumoniae, and a severe defect in leukocyte adhesion and T-cell activation (3). They also have a defect in leukocyte recruitment to peritonitis (35), and a lack of neutrophil recruitment to the skin (36). The unexpected severity of the $\mathrm{CD} 18^{-/-} \mathrm{CD} 62 \mathrm{E}^{-/-}$mouse phenotype suggests that $\mathrm{CD} 18$ integrins and E-selectin serve a common function at a critical juncture or bottleneck in the leukocyte adhesion cascade, at the transition from rolling to firm adhesion.

Although we found many phenotypic differences between $C D 18^{-/-} \mathrm{CD} 62 \mathrm{E}^{-/-}$mice and single mutants, our search for a cause of lethality was not successful. Neither the skin lesions, the neutrophil accumulation in the lungs, nor the hematopoietic changes and splenomegaly are likely causes for early death and failure to thrive. However, the combination of these defects may well be the cause of the reduced viability.

The severe phenotype seen in $\mathrm{CD} 18^{-/-} \mathrm{CD} 62 \mathrm{E}^{-/-}$mice is somewhat reminiscent of $\mathrm{E}$ - and P-selectin doublemutant $\left(\mathrm{CD} 6 \mathrm{E}^{-/-} \mathrm{CD} 62 \mathrm{P}^{-/-}\right)$mice. $\mathrm{CD} 62 \mathrm{E}^{-/-} \mathrm{CD} 62 \mathrm{P}^{-/-}$ mice develop spontaneous mucocutaneous infections with skin ulcerations, even in a specific pathogen-free environment. They have very high circulating neutrophil counts (elevated 10- to 20-fold), which are thought to result from either an inability to recruit neutrophils to sites of inflammation, elevated circulating inflammatory cytokines (11), or alterations in the hematopoietic system $(12,37)$. CD62 $E^{-/-} C D 62 P^{-/-}$mice demonstrate no leukocyte rolling after tissue trauma or after short-term cytokine treatment (11), but after prolonged (6-8 hour) cytokine treatment (6), these mice show a small number of rolling leukocytes and significant leukocyte recruitment. Similar to the current findings, E- and P-selectin were identified as serving an overlapping function at a critical juncture in the inflammatory adhesion cascade, namely, stable leukocyte rolling (11).

Two other mice with mutations in genes encoding for inflammatory adhesion molecules, $\alpha_{4}$ integrins (38) and VCAM-1 (39), have produced a lethal phenotype. However, in these mice, lethality was not caused by an inflammatory defect, but by developmental defects affecting the formation of the chorioallantoic fusion $(38,39)$, epicardium, and coronary arteries (38). Although the phenotype of E- and P-selectin double-mutant mice is severe, it did not lead to reduced viability of juvenile mice. Therefore, the CD $18^{-/-} \mathrm{CD} 62 \mathrm{E}^{-/-}$mouse represents the most severe inflammatory defect yet described.

One of the striking phenotypic traits of the $\mathrm{CD} 18^{-/-} \mathrm{CD} 62 \mathrm{E}^{-/-}$mice is their high circulating neutrophil count. In previous studies with several other adhesion molecule-mutant mice, high circulating neu-

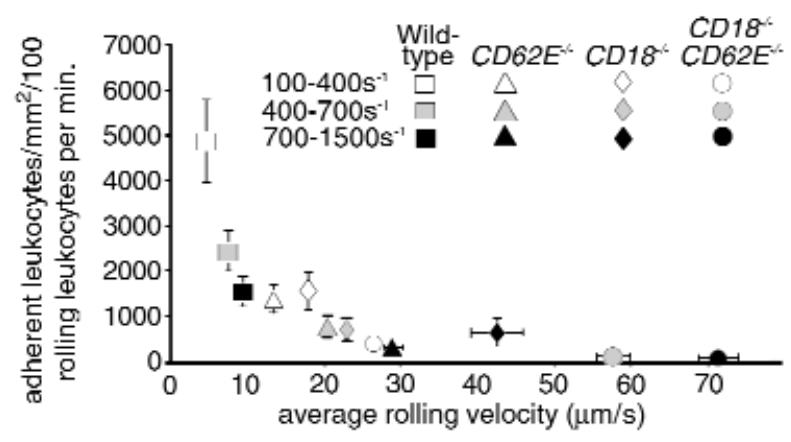

Figure 8

Inverse correlation between leukocyte rolling velocity and leukocyte adhesion efficiency in TNF- $\alpha$-treated cremaster muscle venules of wild-type mice (squares), CD62 $E^{-/-}$mice (triangles), $C D 18^{-/-}$mice (diamonds), and $C D 18^{-/-} C D 62 E^{-/-}$mice (circles). Adhesion efficiency, represented as the ability of rolling leukocytes to become adherent, was drastically reduced as the leukocyte rolling velocity was increased. Data represented as mean \pm SEM (SEM not shown if smaller than symbol). 

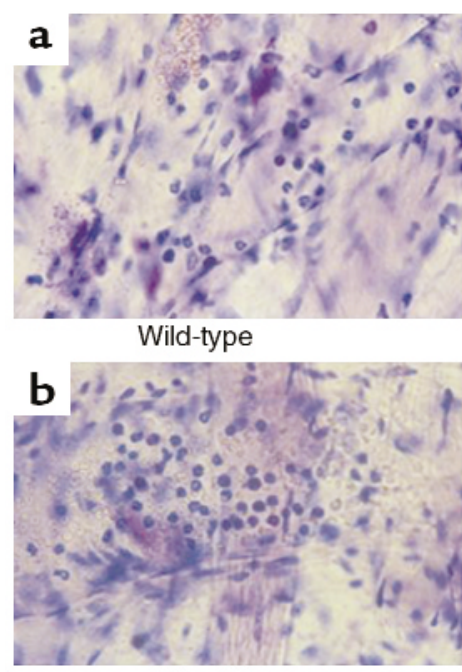

CD62E

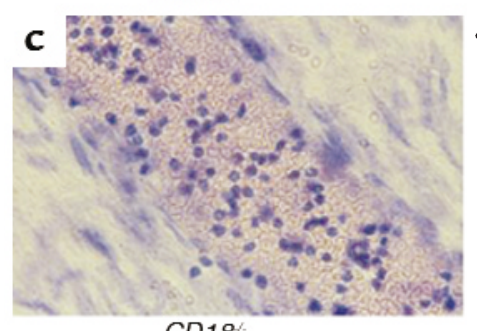

CD18

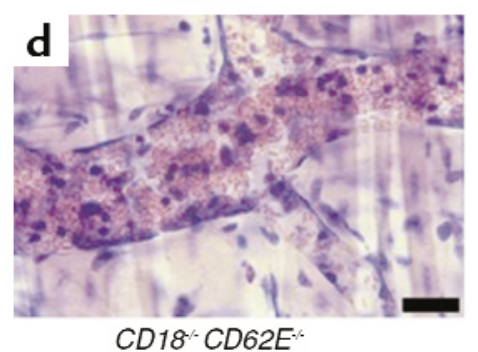

h

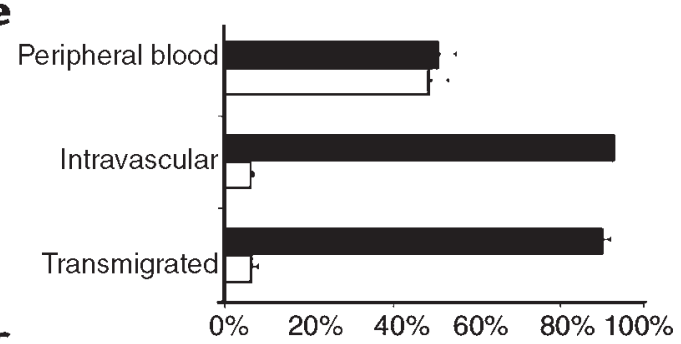

f

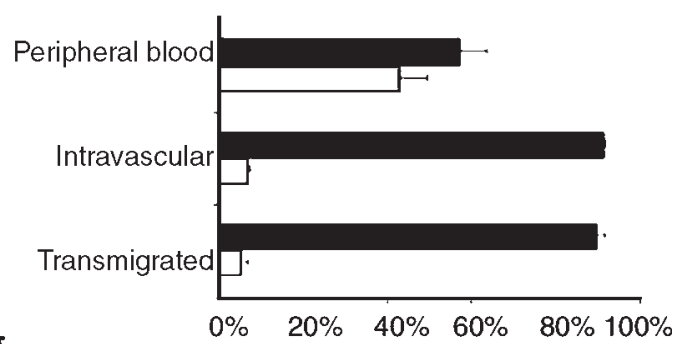

g
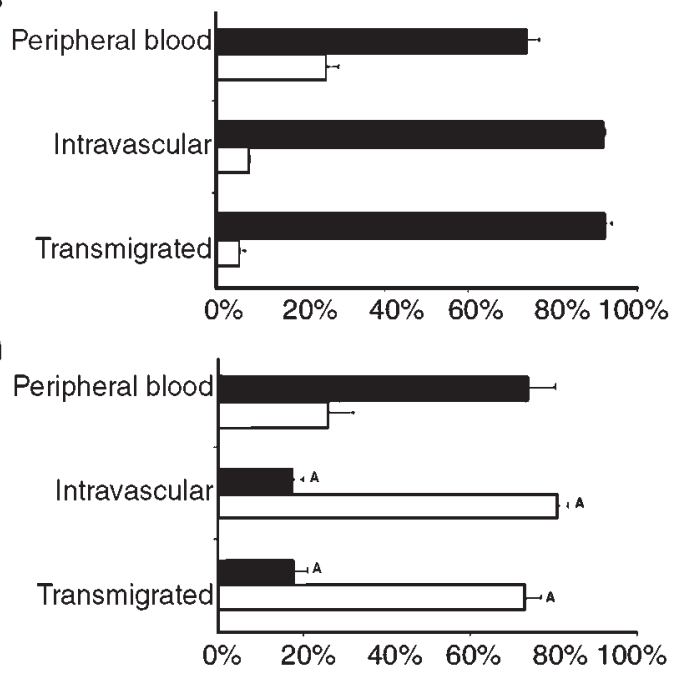

Figure 9

Differentiation of intravenular leukocytes. Left column shows a representative venule for each genotype. Whole mounts were obtained from wild-type (a), CD62E-/- (b), CD18 ${ }^{-/-}$(c), and CD18 ${ }^{-/}$CD $62 E^{-/-}$mice $(\mathbf{d})$ and stained with Giemsa. Bar = $20 \mu \mathrm{m}$. (e-h) Differential leukocyte counts in blood and cremaster venules, and transmigrated leukocytes in cremaster tissue. Filled bars, neutrophils; open bars, mononuclear cells. ${ }^{A} P<0.05$ compared with all other groups. trophil counts have been observed. Mild elevations were seen in ICAM-1-/-, LFA-1 $1^{-/}$, and P-selectin-null mice $(7,18)$. Severe elevations were found in CD $62 E^{-/-} C D 62 P^{-/-}$mice $(11,12)$ and $C D 18^{-/-}(3)$ mice. Some strains were investigated for possible causes of these elevated counts. In $C D 62 E^{-/-} C D 62 P^{-/-}$mice, elevated levels of GM-CSF and altered hematopoiesis (12) have been described. We also found elevated GM-CSF in $C D 18^{-/-} \mathrm{CD} 62 E^{-/-}$mice. However, GM-CSF is unlikely to be a primary causative factor for elevated neutrophil counts (40). We hypothesized that G-CSF would be a more likely candidate, based on the phenotype of the G-CSF-overexpressing transgenic mice and G-CSF-null mice (41), which have severe neutrophilia and neutropenia, respectively. G-CSF is considered to be the major regulator of granulocyte production (42), and our finding that $C D 18^{-/-} C D 62 E^{-/-}$mice exhibit increased plasma G-CSF levels associated with neutrophilia supports this conclusion. The findings of extramedullary hematopoiesis in the spleen and the elevated percentage of neutrophil precursors are both consistent with a severe hematopoietic dysregulation in $C D 18^{-/-} \mathrm{CD} 62 \mathrm{E}^{-/-}$mice.
Our intravital microscopy findings in $\mathrm{CD} 18^{-/-} \mathrm{CD} 62 \mathrm{E}^{-/-}$ mice confirm and extend previous findings made in CD18 ${ }^{-/-}$mice treated with an E-selectin antibody (23). We now show that the defect of slow leukocyte rolling is dependent on wall shear rate, and, by inference, wallshear stress (which is directly related to wall shear rate). In wild-type mice, rolling velocity is almost invariant over a wide range of wall shear rates in TNF- $\alpha$-induced inflammation; even when E-selectin is missing, the dependence on wall shear rate is moderate, although the rolling velocities are increased throughout. However, eliminating CD18 has a large impact on rolling velocities at high wall shear rates. The shear-rate influence is strongest in the $C D 18^{-/-} \mathrm{CD} 62 \mathrm{E}^{-/-}$double-mutant mice. In $C D 18^{-/-} \mathrm{CD} 62 \mathrm{E}^{-/-}$mice, leukocyte recruitment is essentially absent in venules with moderate $\left(400-700 \mathrm{~s}^{-1}\right)$ or high $\left(>700 \mathrm{~s}^{-1}\right)$ shear rates. Only a very modest rate of recruitment is possible in the venules with the slowest flow (wall shear rate $<400 \mathrm{~s}^{-1}$ ). This is significant for two reasons. First, venules with shear rates above $400 \mathrm{~s}^{-1}$ are common in most microcirculatory beds. Although complete samples are rarely reported $(43,44)$, it is estimated that about two-thirds of venules fall in this shear-rate 
range. Second, leukocyte delivery is directly proportional to flow rate, which has a linear dependence on bloodflow velocity and a quadratic dependence on vessel radius. On average, higher wall shear rates are observed more frequently in larger venules, whereas the small postcapillary venules show the lowest wall shear rates. This means that in $C D 18^{-/-} C D 62 E^{-/-}$mice, the most important venules, carrying the most leukocytes, are eliminated from contributing to leukocyte recruitment.

In conclusion, we have identified an overlapping function of CD18 integrins and E-selectin at a crucial step in the leukocyte adhesion cascade. Apparently, no other molecules can substitute for the essential function of these molecules in converting rolling to firm adhesion. This leads to severe inflammatory impairment and severely reduced viability in $C D 18^{-/-} C D 62 E^{-/-}$mice.

\section{Acknowledgments}

We thank Russell Lindsey (University of Alabama at Birmingham) for the detailed histological analysis. Funding for the study was provided by NIH grants HL54136 to K. Ley and AI-32177 to A.L. Beaudet. S.B. Forlow was supported by NRSA HL-10447.

1. Butcher, E.C. 1991. Leukocyte-endothelial cell recognition: three (or more) steps to specificity and diversity. Cell. 67:1033-1036.

2. Kansas, G.S. 1996. Selectins and their ligands: current concepts and controversies. Blood. 88:3259-3287.

3. Scharffetter-Kochanek, K., et al. 1998. Spontaneous skin ulceration and defective T cell function in CD18 null mice. J. Exp. Med. 188:119-131.

4. Arfors, K.E., et al. 1987. A monoclonal antibody to the membrane glycoprotein complex CD18 inhibits polymorphonuclear leukocyte accumulation and plasma leakage in vivo. Blood. 69:338-340.

5. Kunkel, E.J., and Ley, K. 1996. Distinct phenotype of E-selectin-deficient mice. E-selectin is required for slow leukocyte rolling in vivo. Circ. Res. 79:1196-1204

6. Jung, U., Ramos, C.L., Bullard, D.C., and Ley, K. 1998. Gene-targeted mice reveal importance of $\mathrm{L}$-selectin-dependent rolling for neutrophil adhesion. Am. J. Physiol. 274:H1785-H1791.

7. Mayadas, T.N., Johnson, R.C., Rayburn, H., Hynes, R.O., and Wagner, D.D. 1993. Leukocyte rolling and extravasation are severely compromised in $\mathrm{P}$ selectin-deficient mice. Cell. 74:541-554.

8. Tedder, T.F., Steeber, D.A., and Pizcueta, P. 1995. L-selectin-deficient mice have impaired leukocyte recruitment into inflammatory sites. J. Exp. Med. 181:2259-2264.

9. Labow, M.A., et al. 1994. Characterization of E-selectin-deficient mice: demonstration of overlapping function of the endothelial selectins. Immunity. 1:709-720.

10. Arbones, M.L., et al. 1994. Lymphocyte homing and leukocyte rolling and migration are impaired in L-selectin-deficient mice. Immunity. 1:247-260.

11. Bullard, D.C., et al. 1996. Infectious susceptibility and severe deficiency of leukocyte rolling and recruitment in E-selectin and P-selectin double mutant mice. J. Exp. Med. 183:2329-2336.

12. Frenette, P.S., Mayadas, T.N., Rayburn, H., Hynes, R.O., and Wagner, D.D 1996. Susceptibility to infection and altered hematopoiesis in mice deficient in both P- and E-selectins. Cell. 84:563-574.

13. Jung, U., and Ley, K. 1999. Mice lacking two or all three selectins demonstrate overlapping and distinct functions for each selectin. J. Immunol. 162:6755-6762.

14. Coxon, A., et al. 1996. A novel role for the $\beta 2$ integrin CD11b/CD18 in neutrophil apoptosis: a homeostatic mechanism in inflammation. Immunity. 5:653-666.

15. Schmits, R., et al. 1996. LFA-1-deficient mice show normal CTL responses to virus but fail to reject immunogenic tumor. J. Exp. Med. 183:1415-1426.

16. Lu, H., et al. 1997. LFA-1 is sufficient in mediating neutrophil emigration in Mac-1-deficient mice. J. Clin. Invest. 99:1340-1350.

17. Xu, H., et al. 1994. Leukocytosis and resistance to septic shock in intercellular adhesion molecule 1-deficient mice. J. Exp. Med. 180:95-109.

18. Sligh, J.E.J., et al. 1993. Inflammatory and immune responses are impaired in mice deficient in intercellular adhesion molecule 1. Proc. Natl. Acad. Sci. USA. 90:8529-8533.

19. Kunkel, E.J., et al. 1996. Absence of trauma-induced leukocyte rolling in mice deficient in both P-selectin and intercellular adhesion molecule 1. J. Exp. Med. 183:57-65.

20. Bullard, D.C., et al. 1995. P-selectin/ICAM-1 double mutant mice: acute emigration of neutrophils into the peritoneum is completely absent but is normal into pulmonary alveoli. J. Clin. Invest. 95:1782-1788.

21. Ley, K., Allietta, M., Bullard, D.C., and Morgan, S. 1998. Importance of Eselectin for firm leukocyte adhesion in vivo. Circ. Res. 83:287-294.

22. Munoz, F.M., Hawkins, E.P., Bullard, D.C., Beaudet, A.L., and Kaplan, S.L. 1997. Host defense against systemic infection with Streptococcus pneumoniae is impaired in E-, P-, and E-/P-selectin-deficient mice. J. Clin. Invest. 100:2099-2106.

23. Jung, U., Norman, K.E., Scharffetter-Kochanek, K., Beaudet, A.L., and Ley, K. 1998. Transit time of leukocytes rolling through venules controls cytokine-induced inflammatory cell recruitment in vivo. J. Clin. Invest. 102:1526-1533.

24. Pries, A.R. 1988. A versatile video image analysis system for microcirculatory research. Int. J. Microcirc. Clin. Exp. 7:327-345.

25. Lipowsky, H.H., and Zweifach, B.W. 1978. Application of the "two-slit" photometric technique to the measurement of microvascular volumetric flow rates. Microvasc. Res. 15:93-101.

26. Reneman, R.S., Woldhuis, B., oude Egbrink, M.G.A, Slaaf, D.W., and Tangelder, G.J. 1992. Concentration and velocity profiles of blood cells in the microcirculation. In Advances in cardiovascular engineering. N.H.C. Hwang, V.T. Turitto, and M.R.T. Yen, editors. Plenum Publishing Corp. New York, New York, USA. 25-40.

27. Ley, K., et al. 1995. Sequential contribution of L-and P-selectin to leukocyte rolling in vivo. J. Exp. Med. 181:669-675.

28. Schwarzenberger, P., et al. 1998. IL-17 stimulates granulopoiesis in mice: use of an alternate, novel gene therapy-derived method for in vivo evaluation of cytokines. J. Immunol. 161:6383-6389.

29. Grisham, M.B., Hernandez, L.A., and Granger, D.N. 1986. Xanthine oxidase and neutrophil infiltration in intestinal ischemia. Am. J. Physiol. 251:G567-G574

30. Hillegass, L.M., Griswold, D.E., Brickson, B., and Albrightson-Winslow, C. 1990. Assessment of myeloperoxidase activity in whole rat kidney. J. Pharmacol. Methods. 24:285-295.

31. Fleming, T.J., Fleming, M.L., and Malek, T.R. 1993. Selective expression of Ly-6G on myeloid lineage cells in mouse bone marrow. RB6-8C5 mAb to granulocyte-differentiation antigen (Gr-1) detects members of the Ly-6 family. J. Immunol. 151:2399-2408.

32. Jung, U., and Ley, K. 1997. Regulation of E-selectin, P-selectin, and intercellular adhesion molecule 1 expression in mouse cremaster muscle vasculature. Microcirculation. 4:311-319.

33. Damiano, E.R., Westheider, J., Tozeren, A., and Ley, K. 1996. Variation in the velocity, deformation, and adhesion energy density of leukocytes rolling within venules. Circ. Res. 79:1122-1130.

34. Lipowsky, H.H., Scott, D.A., and Cartmell, J.S. 1996. Leukocyte rolling velocity and its relation to leukocyte-endothelium adhesion and cell deformability. Am. J. Physiol. 270:H1371-H1380.

35. Walzog, B., Scharffetter-Kochanek, K., and Gaehtgens, P. 1999. Impairment of neutrophil emigration in CD18-null mice. Am. J. Physiol. 276:G1125-G1130

36. Mizgerd, J.P., et al. 1997. Neutrophil emigration in the skin, lungs, and peritoneum: different requirements for CD11/CD18 revealed by CD18-deficient mice. J. Exp. Med. 186:1357-1364

37. Frenette, P.S., Subbarao, S., Mazo, I.B., von Andrian, U.H., and Wagner, D.D. 1998. Endothelial selectins and vascular cell adhesion molecule-1 promote hematopoietic progenitor homing to bone marrow. Proc. Natl. Acad. Sci. USA. 95:14423-14428

38. Yang,J.T., Rayburn, H., and Hynes, R.O. 1995. Cell adhesion events mediated by alpha 4 integrins are essential in placental and cardiac development. Development. 121:549-560.

39. Gurtner, G.C., et al. 1995. Targeted disruption of the murine VCAM1 gene: essential role of VCAM-1 in chorioallantoic fusion and placentation. Genes Dev. 9:1-14.

40. Stanley, E., et al. 1994. Granulocyte/macrophage colony-stimulating factor-deficient mice show no major perturbation of hematopoiesis but develop a characteristic pulmonary pathology. Proc. Natl. Acad. Sci. USA. 91:5592-5596.

41. Lieschke, G.J., et al. 1994. Mice lacking granulocyte colony-stimulating factor have chronic neutropenia, granulocyte and macrophage progenitor cell deficiency, and impaired neutrophil mobilization. Blood. 84:1737-1746.

42. Metcalf, D. 1995. The granulocyte-macrophage regulators: reappraisal by gene inactivation. Exp. Hematol. 23:569-572.

43. Pries, A.R., Fritzsche, A., Ley, K., and Gaehtgens, P. 1992. Redistribution of red blood cell flow in microcirculatory networks by hemodilution. Circ. Res. 70:1113-1121.

44.Zweifach, B.W., and Lipowsky, H.H. 1984. Pressure-flow relations in blood and lymph microcirculation. In Handbook of physiology. The cardiovascular system. Microcirculation. E.M. Renkin and C.C. Michel, editors. American Physiological Society. Bethesda, Maryland, USA. 251-307. 